\section{In brief \\ Thousands of families to sue over retained organs}

China confirms three cases of SARS: The Chinese authorities have confirmed three cases of severe acute respiratory syndrome (SARS) so far this year. Traces of the virus were found in cages used to house civets in a restaurant where one of the women who contracted SARS worked, though experts are not sure that that was the mode of transmission. The source of infection for the other two cases is not yet known.

Polio immunisation campaign misses 300 000: Although India's health ministry has declared its intention to wipe out poliomyelitis by the end of 2004, at least 300000 children were not covered in the recent "pulse polio immunisation" programme in west Bengal. The state government blamed cold and rainy weather for the programme's shortcomings.

\section{Vietnam confirms fifth death} from avian flu: The World Health Organization has confirmed a fifth death as a result of the $\mathrm{H} 5 \mathrm{~N} 1$ avian flu outbreak in Vietnam, and more suspected cases are emerging at two Hanoi hospitals. More than two million chickens have been slaughtered in an attempt to bring the outbreak under control. So far, there have been no confirmed cases of human to human transmission.

\section{Plea for some patients to be} exempt from smoking ban: A majority of Dutch MPs are urging that new regulations banning smoking in public places be relaxed in the case of elderly, nursing, and care homes, and psychiatric institutions. They have argued patients should not be "denied their last pleasures."

GMC investigates wife of pathologist van Velzen: The General Medical Council is investigating Dr Lynne Ball, a former consultant at Alder Hey Hospital in Liverpool. Dr Ball is the wife of Professor Dick van Velzen, former pathologist at the hospital, whom the GMC barred from practising in Britain after he was found to have retained thousands of children's organs without consent (BMJ 2001;322: 255). The GMC refused to comment on the nature of the allegations against Dr Ball.
Clare Dyer legal correspondent, BMJ

Thousands of families of people whose organs had been retained without consent by the NHS were getting ready to take their compensation battle to the High Court in London as the BMJ went to press.

More than 2000 families were set to go to court next Monday for the start of a four week hearing, after they rejected compensation offers as being too low.

The claimants, who are suing NHS trusts all over England, claim that the compensation offered-thought to be about $£ 1000$ (\$1780; €1440) eachcompares unfavourably with the $£ 5000$ paid to parents of children whose organs were retained by the Alder Hey children's hospital in Liverpool. They insist, however, that the litigation is not about money, which could never make up for the trauma they experienced.

The Department of Health said it had urged both sides to reach a "reasonable and amicable settlement" to avoid incurring the huge costs of a four week trial.

Mervyn Fudge, solicitor for about 1500 families, said that the level of compensation offered to families who were not covered by the Alder Hey group litigation 18 months ago left them with no choice but to go to court.

The court case coincides with the parliamentary passage of the Human Tissue Bill, designed to prevent such cases occurring in future. The bill makes consent the cornerstone of legislation.

Doctors removing organs without consent will face sentences of up to three years in prison and unlimited fines. A new Human Tissue Authority will license and inspect premises and enforce a code of conduct.

The BMA accused the government of "wasting an opportunity" to ease the shortage of donor organs by not including a provision whereby people were deemed to have consented to the use of their organs after their death unless they opted out.

Dr Michael Wilks, chairman of the BMA's ethics committee, said, "There is an increasing gap between the supply of organs for

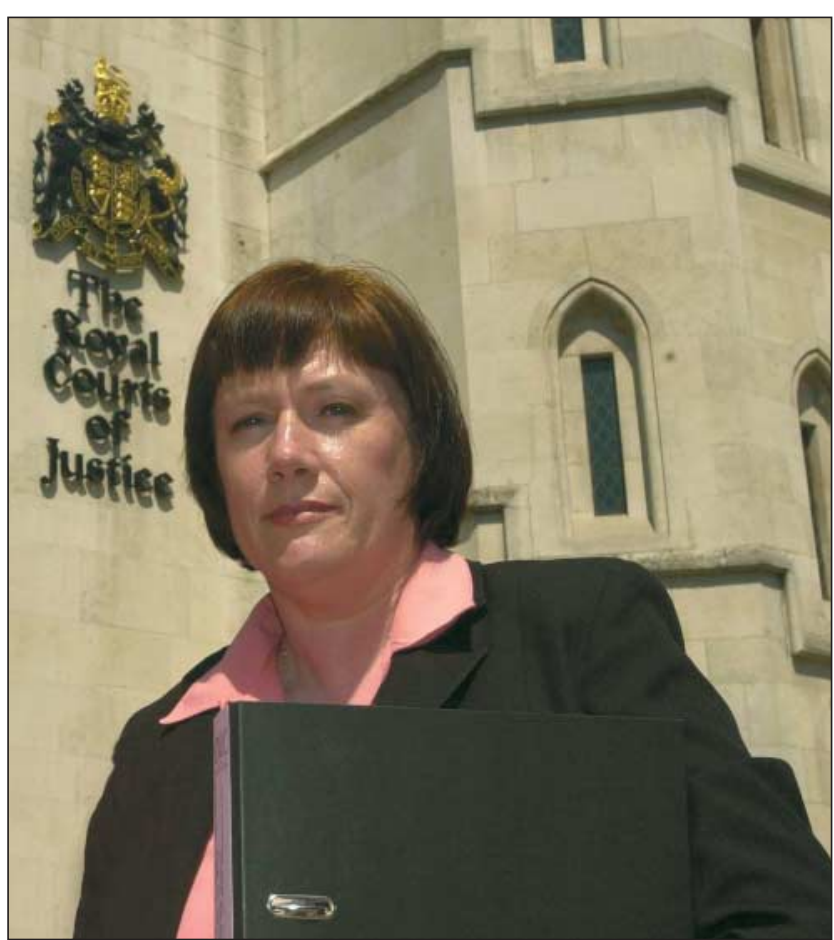

Ruth Webster of Leeds, who is the coordinator of the National Committee Relating to Organ Retention which represents many of the families, discovered that most of her baby's organs were removed donation and the numbers of people requiring a transplant. A system of presumed consent could go some way to bridging this gap.

"The BMA supports a 'soft' system of presumed consent in which relatives' views are also taken into account. The crucial difference would be in the approach to relatives. Instead of being asked to consent to donation, they would be informed that their relative had not opted out of donation. Unless they objected-either because they knew their relative would not want to donate their organs or because it would cause the family major distress-the donation would proceed."

But the government rejected the calls for a system of presumed consent for organ donation. Health minister Rosie Winterton said informed consent was a key principle underlying the bill, which would improve public confidence "so people will be more willing to agree to valuable uses of tissue and organs for research and transplantation."

However, Cancer Research $\mathrm{UK}$, and the biomedical research charity the Wellcome Trust, warned that the bill could have serious unintended repercussions for research.

Dr Mark Walport, director of the Wellcome Trust, said the bill left it "unclear what research can and cannot be done." The bill could have "unintended consequences by preventing some types of lifesaving research," he said.

For example, it might not have been possible and might even have been criminal, if the bill was in force, to do the research that led to the discovery of genes responsible for the most common inherited form of breast cancer. And scientists might not have been able to study postmortem samples to identify new variant CreutzfeldtJakob disease.

"The serious, unintended consequences of this bill must be resolved to safeguard vital medical research which could ultimately affect millions of people," he added.

Cancer Research UK said it had particular concerns over plans to regulate human genetic research, which could prohibit studies on stored DNA samples taken before the introduction of the bill. 